\title{
Value and growth stocks in Brazil: risks and returns for one- and two-dimensional portfolios under different economic conditions
}

\section{Ações de valor e de crescimento no Brasil: riscos e retornos de carteiras uni e bidimensionais em diferentes estados da economia}

Leandro da Rocha Santos

Professor Mestre em Administração - Grupo IBMEC Educacional S.A.

E-mail: Irochasantos@yahoo.com

Roberto Marcos da Silva Montezano

Professor Titular em Economia - Grupo IBMEC Educacional S.A.

E-mail: rmontezano@ibmecrj.br

Recebido em 24.11.2010 - Aceito em 11.01.2011 - 3ª versão aceita em 29.04.2011

ABSTRACT

For empirical purposes, value stocks are usually defined as those traded at low price-to-earnings ratios (stock prices divided by earnings per share), low price-to-book ratios (stock prices divided by book value per share) or high dividend yields (dividends per share divided by stock prices). Growth stocks, on the other hand, are traded at high price-to-earnings ratios, high price-to-book ratios or low dividend yields. Academic research so far produced, international and Brazilian alike, shows that value stocks outperform growth stocks, challenging the Efficient Market Hypothesis, which states that the market prices of traded stocks are the best estimate of their intrinsic values. Most studies use a single ratio to sort stocks on percentiles; risks (generally defined as beta or standard deviations) and returns are then calculated for the resulting value and growth portfolios. In the present paper, we aim to further contribute to the growing literature on the field by applying a method not previously tested on the Brazilian market. We build portfolios sorted by the price-to-earnings and price-to-book ratios alone and by a combination of both in order to assess value and growth stocks' risks and returns on the Brazilian stock market between 1989 and 2009. Furthermore, our risk analysis may be regarded as the paper's main contribution, since its approach departs from conventional risk concepts, as we not only test for beta: portfolios' returns are measured under different economic conditions. Results support a pervasive value premium in the Brazilian stock market. Risk analysis shows that this premium holds under every economic condition analyzed, suggesting that value stocks are indeed less risky. Beta proved not to be a satisfactory risk measure. Portfolios sorted by the price-to-earnings ratio yielded the best results.

Keywords: Value Stocks. Growth Stocks. Market Efficiency. Emerging Markets. Brazilian Stocks. BM\&FBovespa.

\section{RESUMO}

Para fins de pesquisas empíricas, ações de valor são geralmente definidas como aquelas negociadas a baixos índices preço/lucro (preço da ação dividido pelos lucros por ação), baixos índices preço/valor patrimonial (preço 
da ação dividido pelo valor patrimonial por ação) ou altos dividend yields (dividendos por ação divididos pelo preço da ação). Ações de crescimento, por outro lado, são aquelas negociadas a altos índices preço/lucro, altos indices preço/valor patrimonial ou baixos dividend yields. Pesquisas acadêmicas brasileiras e internacionais mostram que as ações de valor têm melhor desempenho do que as de crescimento, contrariando a Hipótese de Mercados Eficientes, que estabelece que os preços de mercado das ações são as melhores estimativas de seus valores intrínsecos. A maioria dos estudos utiliza um único múltiplo para classificar carteiras em percentis; riscos (geralmente definidos como coeficiente beta ou desvio-padrão) e retornos são então calculados para as carteiras de valor e de crescimento. No presente paper, busca-se contribuir para a crescente literatura sobre o tema empregando uma metodologia ainda não testada no mercado brasileiro. Construíram-se carteiras classificadas pelos índices preço/lucro e preço/valor patrimonial, isoladamente e em conjunto, para calcular riscos e retornos no mercado acionário brasileiro no período 1989-2009. Ademais, a análise de risco pode ser considerada a principal contribuição do paper, uma vez que a abordagem diverge de tradicionais métricas de risco, já que não se testou apenas o coeficiente beta: os retornos das carteiras são medidos em diferentes estados da economia. Os resultados indicam um consistente prêmio de valor no mercado acionário brasileiro. A análise de risco mostra que esse prêmio ocorre em todos os estados da economia analisados, o que sugere que as ações de valor são realmente menos arriscadas. O beta não se mostrou uma medida satisfatória de risco. As carteiras classificadas pelo índice preço/lucro produziram os melhores resultados.

Palavras-chave: Ações de Valor. Ações de Crescimento. Eficiência de Mercado. Mercados Emergentes. Ações Brasileiras. BM\&F Bovespa

\section{INTRODUCTION}

Academic research on Value Investing seemed to lie dormant well into the 1990s, in spite of the pioneering study by Basu (1977), the half-century-old teachings of Benjamin Graham - who, on 1934, laid bare the foundations of the discipline (GRAHAM AND DODD, 1934) - and the remarkable investment stories of many of his followers, notably Berkshire Hathaway's Warren Buffett, whose 24-year-long investment history produced a 20.3\% compounded growth (BUFFETT, 2010). Part of the blame can be attributed to the intellectual dominance of the Efficient Markets School (EMS), whose models and theories became the paradigms of choice of the academic community. In a nutshell, the EMS propounds that agents are rational, the market prices of tradable securities are the best estimate of their intrinsic values and higher returns always entail higher risks (for a brief overview of market efficiency, see DIMSON AND MUSSAVIAN, 1998. The EMS has been criticized by, among others, MANDELBROT, 2004). Conversely, Value Investing's practitioners regard markets as inherently inefficient: investors often bid market prices away from intrinsic values, allowing for the purchase of undervalued securities, which tend to produce better returns in the long run (see GREENWALD ET AL., 2001). Rationality is indeed limited, for market agents are human beings, psychologically and neurologically unfit for investing (see BARBERIS AND THALER, 2003 and ZWEIG, 2007), who from time to time fall victim to market fads (see KINDLEBERGER, 2005 and CHANCELLOR, 2000).

According to Chan and Lakonishok (2004), researchers' interest was aroused by the studies of Fama and French (1992) and Lakonishok et al. (1994). Both have shown that value stocks outperform growth stocks (for empirical purposes, value stocks are defined as stocks traded at low market prices relative to fundamentals like net profits, book value, sales and dividends. The opposite holds true for growth stocks). In their line of research, a plethora of studies on different markets helped to establish Value 
Investing's dominance, casting doubts on the EMS’ propositions. Nonetheless, given the worldwide publicity of the studies, the reasons for the superior performance remain controversial. Market efficiency-oriented researchers view value stocks as inherently riskier than growth stocks, yielding, therefore, higher returns. They take this stance despite the fact that traditional risk measures, such as beta and standard deviation, are shown to be generally smaller for value stocks (or, at most, disproportionately small relative to their higher returns). Behavioral-oriented researchers, on the other hand, view value stocks as less risky than growth stocks and maintain that their superior performance stems from behavioral and agency issues.

Most studies so far produced, international and Brazilian alike, focus on what can be dubbed one-dimensional strategies. A single multiple such as price-to-earnings $(\mathrm{P} / \mathrm{E}$, the ratio of the stock's market price to the company's profits) or price-to-book $(\mathrm{P} / \mathrm{B}$, the ratio of the stock's market price to the company's book value) is used to sort stocks into percentiles, producing different portfolios. The one with the lowest multiples stands for the value ("cheap") portfolio; at the other end of the spectrum lies the growth ("expensive") portfolio. Risks and returns are then calculated for each portfolio.

The economic motivation for selecting stocks according to these multiples comes primarily from two behavioral issues: overreaction and reversion to the mean. Graham (2006) sustains that the "manicdepressive Mr. Market" overreacts, leading securities' prices, momentarily or throughout long periods, away from their intrinsic values and their historical average. Debondt and Thaler (1985) tested the overreaction hypothesis and concluded that losing portfolios (made up of stocks that underperformed the market in the five years prior to portfolio formation) outperformed winning portfolios (those that outperformed the market in the five years prior to portfolio formation), even though the latter were riskier. Debondt and Thaler (1989) also tested the reversion to the mean hypothesis and concluded that stock prices do revert to the mean, either in a long-term perspective or after extreme market movements. Thus, low $\mathrm{P} /$ Es and low $\mathrm{P} / \mathrm{Bs}$ are expected to capture, in a single metric, the excesses of pessimism and the failure of investors to consider reversion to the mean.

This line of research was somewhat changed by the aforementioned study by Lakonishok et al. (1994) in two equally relevant ways. First, they put forward the concept of a two-dimensional strategy in which two variables are combined, so that the resulting portfolios take account of both past and future performance. This strategy outperformed one-dimensional strategies and its rationale is explained, according to the authors, by the belief that stocks become over or underpriced due to various reasons, ranging from "extrapolating past earnings growth too far into the future, to assuming a trend in stock prices, to overreacting to good and bad news, or to simply equating a good investment with a well-run company irrespectiveofprice" (LAKONISHOKETAL., 1994, p. 1542). The authors therefore define growth stocks as those that have performed well in the past and are expected to perform well in the future. As investors bid them up, they become overpriced. The opposite happens to stocks that have shown poor past performances: they are dumped by investors, becoming underpriced value stocks. Second, they went beyond traditional risk measures as they measured the performance of value and growth portfolios in different states of the economy. The underlying assumption was that value stocks would be riskier than growth stocks if they underperformed the latter in "bad" states of the economy, such as recessions and bear markets, due to the fact that, in these states, the marginal utility 
of wealth is higher. Their results have shown that value stocks are indeed less risky since they outperform growth stocks in every state of the economy analyzed and, most important of all, the results are even better in negative states.

Following in their footsteps, Chin et al. (2002) tested two-dimensional strategies in the New Zealand market and found that they outperform one-dimensional strategies. They did not, however, test the risk proposition advanced by Lakonishok et al. (1994). Athanassakos (2009), on the other hand, tested the risk proposition for portfolios sorted on $\mathrm{P} / \mathrm{E}$ and $\mathrm{P} / \mathrm{B}$ alone and alongside beta and size on the Canadian stock market. He found evidence of a pervasive value premium and better performances for the value strategy in every state of the economy analyzed.

To our knowledge, no previous study on the Brazilian market tested both propositions. One-dimensional and multivariate studies abound, showing that value stocks outperform growth stocks and are generally less risky (see, for example, RAMOS ET AL., 2000, ROSTAGNO ET AL., 2003, BRAGA AND LEAL, 2004, LOPES AND GALDI, 2007 and GALDI, 2008). None of them, however, tested for the two-dimensional strategies put forward by Lakonishok et al (1994). Risk analyses are generally based on traditional risk measures such as beta, standard deviation and the Sharpe Coefficient, but not on the assessment of risks under different states of the economy, which casts a wholly different light upon the subject, as it does not equate risk with volatility (arguably, volatility, by itself, might not be a proper risk measure for investors with long-term horizons). Moreover, most Brazilian studies focus on 10-year periods at most. Our paper, on the other hand, encompasses a 20 -year period which, besides the obvious advantage of length, was shaped by five years of rampant hyperinflation and 15 years of monetary stability.
Thus, the present paper aims to contribute to the growing academic literature by doing both. Throughout a 20-year period, we test for one- and twodimensional strategies on the Brazilian stock market and measure the risk of both strategies, assessing their performance in different states of the economy. For the sake of completeness, we also test for beta.

Before discussing our method, we present a brief summary of the key results found in the literature. Fama and French (1992) studied the American market from 1963 to 1990 and found a monthly value premium of 1.53 percentage points (p.p.) when sorting on $\mathrm{P} / \mathrm{Es}$ and one of 0.68 p.p when sorting on $\mathrm{P} / \mathrm{Bs}$ (betas were almost identical). Lakonishok et al (1994) tested different sorting strategies in the same market and period. When sorting on P/Es and $\mathrm{P} / \mathrm{Bs}$, for example, they found 5-year compound premiums of 67 p.p. and 90 p.p. respectively (again, the differences in betas were negligible). When using twodimensional strategies, they attained a 104 p.p. 5-year composite value premium for the pair of variables P/E and GS (growth of sales). As already mentioned, value portfolios performed better in bad states of the economy, being thus less risky. Chin et al (2002) found a 78 p.p. three-year compound cumulative value premium for the two-dimensional $\mathrm{P} / \mathrm{E}+\mathrm{P} / \mathrm{B}$ portfolio on the New Zealand market during the 1988-1995 period. Athanassakos (2009) investigated the Canadian market, using data from the 1985-2005 period, and found an average yearly value premium of 6.30 p.p. (when sorting on P/Es) and a consistent outperformance of the value portfolios in every state of the economy analyzed.

Brazilian studies reached similar conclusions. Ramos et al. (2000) found lower risks for value stocks and a cumulative 114.30 p.p. value premium on $\mathrm{P} / \mathrm{B}$-sorted portfolios during the 1988- 
1994 period. Rostagno et al. (2003) tested various value strategies throughout the 1994-2003 period. They found lower risks (measured as better Sharpe ratios) and a cumulative 304.57 p.p. value premium on P/E-sorted portfolios. Braga and Leal (2004) investigated the 1991-1998 period, using deflated numbers. They found a cumulative 155.03 p.p. value premium on P/B-sorted portfolios and better Sharpe ratios for value stocks. Lopes and Galdi (2007) tested the Brazilian market from
1994 to 2004 and found that value stocks (sorted by $\mathrm{P} / \mathrm{B}$ ) that are financially strong do generate higher returns than financially weak value stocks. The premium for twoyear market adjusted returns was 77.8 p.p. They point out, however, that results were largely influenced by "small, low liquidity or highly indebted firms" (LOPES AND GALDI, 2007). Galdi (2008) applied a similar approach using $\mathrm{P} / \mathrm{E}$ instead of $\mathrm{P} / \mathrm{B}$. Premiums for portfolios held for two years amounted to $109.6 \mathrm{pp}$.

\section{RESEARCH METHOD}

Our data set comprises the period from December 1988 to April 2009. We build onedimensional portfolios sorted by the $\mathrm{P} / \mathrm{E}$ and the $\mathrm{P} / \mathrm{B}$ ratios. The two-dimensional portfolios combine both ratios. We apply a buy-and-hold strategy and our portfolios are built every April $30^{\text {th, }}$ to ensure that accounting results for the previous fiscal year (earnings per share and book value) were already made public. Thus, $\mathrm{P} / \mathrm{Es}$ are defined as the stock's market prices on April 30 th of year $t$ divided by the respective earnings per share on year $t-1$. $\mathrm{P} / \mathrm{Bs}$ use book value on the denominator. Therefore, the first portfolios are built using market prices on April 30th, 1989 and each firm's
1988 accounting results. Portfolios are held for a year and the corresponding returns and betas are then calculated using market prices on April $30^{\text {th }}$ of the year subsequent to the portfolio's formation. The last portfolios are built on 2008, using 2007 accounting data and 2009 market data for the measurement of returns.

In the one-dimensional strategy, we sort stocks into quartiles. The first quartile, the one with the lowest $\mathrm{P} / \mathrm{Es}$ or $\mathrm{P} / \mathrm{Bs}$, represents the value portfolio; the fourth, the growth portfolio. For the two-dimensional strategy, we take intersections to build the portfolios shown below in Table 1. Portfolio 1 stands for the value portfolio; Portfolio 9 for the growth portfolio.

Table 1 Resulting portfolios for the two-dimensional strategy

\begin{tabular}{l|l|l|l|l|l|l|l|l|l}
\hline Ratio & Portfolio 1 & Portfolio 2 & Portfolio 3 & Portfolio 4 & Portfolio 5 & Portfolio 6 & Portfolio 7 & Portfolio 8 & Portfolio 9 \\
\hline P/E & Q1 & Q1 & Q1 & Q2, Q3 & Q2, Q3 & Q2, Q3 & Q4 & Q4 & Q4 \\
\hline P/B & Q1 & Q2, Q3 & Q4 & Q1 & Q2, Q3 & Q4 & Q1 & Q2, Q3 & Q4 \\
\hline
\end{tabular}

All portfolio returns are equally weighted. We do not calculate market-adjusted returns since we do not aim to compare portfolios returns with the overall market returns, but rather to assess the value premium (measured as the spread between the value and the growth portfolios) throughout different holding periods. When calculating returns, we do not account for taxes and transaction costs.

We use Brazilian Central Bank data for per capita GDP and Economatica's database for accounting and market data, which are adjusted for splits, reverse stock splits and dividends and deflated by IPCA, a Brazilian consumer price index. Deflated 
numbers are central to our model for two reasons: first, our data set comprises both the 1989-1993 hyperinflation period (prior to the advent of the "Plano Real") and the post-1994 more stable period and second, there is a gap between the publication of accounting statements and the date established for the portfolios' construction (April, 30 $0^{\text {th }}$ ). It should also be underlined that Brazilian accounting rules prior to 1994 allowed for balance sheet adjustments for inflation (for the reason that the figures would otherwise be meaningless). These adjustments were already factored in the data provided by Economatica.

To ensure an adequate degree of liquidity, we limit our sample to the top 100 non-financial Brazilian companies by market value. We exclude companies that have shown accounting losses or negative book value in the fiscal year prior to portfolio formation. We also exclude stocks that were not traded on April, $30^{\text {th }}$ of the subsequent year. As a result, the number of stocks in our sample ranged from 45 to 94 , 81 being the average.

To test the risk proposition advanced by Lakonishok et al. (1994), we define four states of the economy: bull and bear markets, expansions and contractions. Bull markets were the years when the Ibovespa stock index grew in real terms (1991, 1993, 1994, 1996, 1997, 1999, 2003-2007); the opposite defines bear markets. Expansions were the years when Brazilian real per capita GDP advanced (1989, 1993-1997, 2000, 2002, 2004-2008); the opposite defines contractions. Besides these four states, we also calculate results for the total period, the first and second half, the 1989-1993 period (the years before the Plano Real, being thus characterized by high inflation and economic instability) and the 1994-
2008 period (a more stable period, insofar as inflation is concerned). Table 2 below shows real per capita GDP change and the inflation-adjusted Ibovespa index (at yearend closing prices) from 1988 to 2008.

Table 2 Real per capita GDP change and inflation-adjusted Ibovespa index (at yearend closing prices)

\begin{tabular}{|c|c|c|}
\hline Year & $\begin{array}{l}\text { Real per capita } \\
\text { GDP change }\end{array}$ & $\begin{array}{l}\text { Inflation-adjusted } \\
\text { Ibovespa index }\end{array}$ \\
\hline 1988 & $-1.9 \%$ & $6,577.68$ \\
\hline 1989 & $1.4 \%$ & $5,909.99$ \\
\hline 1990 & $-7.1 \%$ & $1,402.07$ \\
\hline 1991 & $-0.7 \%$ & $5,914.70$ \\
\hline 1992 & $-2.2 \%$ & $5,412.81$ \\
\hline 1993 & $3.3 \%$ & $11,629.84$ \\
\hline 1994 & $4.2 \%$ & $13,495.03$ \\
\hline 1995 & $2.6 \%$ & $10,702.52$ \\
\hline 1996 & $0.6 \%$ & $15,996.24$ \\
\hline 1997 & $1.8 \%$ & $22,017.27$ \\
\hline 1998 & $-1.5 \%$ & $14,410.80$ \\
\hline 1999 & $-1.2 \%$ & $33,325.95$ \\
\hline 2000 & $2.8 \%$ & $28,076.34$ \\
\hline 2001 & $-0.2 \%$ & $23,201.19$ \\
\hline 2002 & $1.2 \%$ & $17,111.33$ \\
\hline 2003 & $-0.2 \%$ & $30,894.01$ \\
\hline 2004 & $4.3 \%$ & $33,824.99$ \\
\hline 2005 & $1.9 \%$ & $40,872.48$ \\
\hline 2006 & $2.7 \%$ & $52,678.30$ \\
\hline 2007 & $4.9 \%$ & $72,443.95$ \\
\hline 2008 & $4.0 \%$ & $40,205.43$ \\
\hline
\end{tabular}

Source: Brazilian Central Bank (2010) and Economatica

We then group the results and present average annual returns, compound annual returns, cumulative returns, betas ${ }^{1}$, the average value premium (the difference between the returns of the value and growth portfolios) and t-statistics for testing the null hypothesis that the mean returns of the value and the growth portfolios are equal. 
Our method entails limitations: a slight survivorship bias, given the fact that we only included in the sample stocks that were being traded one year after portfolio formation; stocks are sorted into quartiles, which might not have been the best way to build portfolios; taxes and transaction costs were not accounted for; we only tested for 20 years, which might seem an eternity in today's hectic investment environment, but is in fact an unrepresentative period for the history of a stock market.

\section{EMPIRICAL RESULTS}

Table 3 below shows the descriptive statistics of our sample.

Table 3 Descriptive statistics of the sample

\begin{tabular}{|c|c|c|c|c|c|c|c|c|}
\hline Year & Stocks & $\begin{array}{l}\text { Stocks } \\
\text { without } \\
\text { Beta }\end{array}$ & $\begin{array}{l}\text { Minimum } \\
\text { P/E }\end{array}$ & Maximum P/E & $\begin{array}{l}\text { Median } \\
\text { P/E }\end{array}$ & $\begin{array}{l}\text { Minimum } \\
\text { P/B }\end{array}$ & Maximum P/B & $\begin{array}{l}\text { Median } \\
\text { P/B }\end{array}$ \\
\hline 1989 & 92 & 10 & 0.01000 & 40.07450 & 4.01826 & 0.00357 & 6.84683 & 0.55333 \\
\hline 1990 & 94 & 9 & 0.00858 & 422.04647 & 1.41395 & 0.00062 & 9.73782 & 0.20077 \\
\hline 1991 & 68 & 18 & 0.26628 & 99.99503 & 2.86410 & 0.00021 & 486.63716 & 0.25284 \\
\hline 1992 & 45 & 9 & 1.06702 & 104.82850 & 8.34132 & 0.00002 & $33,603.47756$ & 0.47685 \\
\hline 1993 & 67 & 15 & 0.01562 & 201.63298 & 7.73828 & 0.00230 & 2.50501 & 0.39991 \\
\hline 1994 & 74 & 12 & 0.79328 & 75.97840 & 7.43639 & 0.07895 & 2.35153 & 0.55846 \\
\hline 1995 & 89 & 14 & 0.04588 & 61.86516 & 6.07080 & 0.00051 & 2.21044 & 0.49928 \\
\hline 1996 & 79 & 18 & 0.00400 & $1,309.82129$ & 5.79644 & 0.00029 & 2.66832 & 0.38199 \\
\hline 1997 & 83 & 16 & 0.01459 & 96.16060 & 8.45044 & 0.00069 & 5.62485 & 0.56389 \\
\hline 1998 & 90 & 9 & 0.00513 & 137.57232 & 5.69077 & 0.00095 & 8.57853 & 0.52780 \\
\hline 1999 & 82 & 17 & 0.00677 & 568.90379 & 4.22422 & 0.00139 & 8.18863 & 0.41460 \\
\hline 2000 & 71 & 5 & 0.03041 & 235.35896 & 7.23674 & 0.00315 & 5.52342 & 0.62990 \\
\hline 2001 & 87 & 6 & 0.03960 & 232.63071 & 5.66952 & 0.00313 & 6.79930 & 0.61311 \\
\hline 2002 & 80 & 10 & 0.95004 & 286.59859 & 5.52774 & 0.12778 & 3.58119 & 0.65305 \\
\hline 2003 & 65 & 10 & 1.64937 & $1,685.64338$ & 5.27123 & 0.11350 & 3.40294 & 0.74346 \\
\hline 2004 & 90 & 8 & 1.18880 & 365.06444 & 6.84994 & 0.10500 & 6.83024 & 1.11880 \\
\hline 2005 & 91 & 13 & 1.72124 & 380.62106 & 8.38224 & 0.09728 & 14.86244 & 1.47170 \\
\hline 2006 & 90 & 17 & 2.42521 & 273.22786 & 9.45302 & 0.33318 & 29.94150 & 2.25758 \\
\hline 2007 & 94 & 13 & 4.15439 & 768.78876 & 18.94758 & 0.28304 & 106.91338 & 3.08907 \\
\hline 2008 & 93 & 6 & 3.21677 & $45,528.03204$ & 16.17229 & 0.31646 & 39.51321 & 2.67677 \\
\hline
\end{tabular}

Our tests point to the unequivocal superiority of the value strategy. As shown in Table 4, one-dimensional $\mathrm{P} / \mathrm{E}$-sorted value portfolios averaged an annual compound return of $22.26 \%$ throughout our 20-year test period, whereas the growth portfolio yielded a negative return of $3.12 \%^{2}$. The value strategy outperformed the growth strategy in each and every period analyzed (the sample's first half, the second half, the years prior to the "Plano Real" and the years afterwards) and the null hypothesis was rejected at the $10 \%$ significance level.

\footnotetext{
2 We excluded from our sample the annual return of $12,415.06 \%$ in the year 2001, which was produced by Petroquisa, a Brazilian petrochemical company. Should we have left it, value stocks would have generated an annual compounded return of $33.58 \%$. Nonetheless, the case for keeping it should be underlined: Petroquisa's P/Es and P/Bs from 1990 to 2001 signaled a major, irrational bargain.
} 
Table 4 Results for one-dimensional P/E-sorted portfolios

\begin{tabular}{|c|c|c|c|c|c|c|}
\hline Period & Metric & $\begin{array}{l}\text { Quartile } 1 \\
\text { (value) }\end{array}$ & $\begin{array}{l}\text { Quartile } 4 \\
\text { (growth) }\end{array}$ & Total sample & $\begin{array}{l}\text { Average value } \\
\text { premium } \\
\text { (Q1-Q4) }\end{array}$ & $\begin{array}{l}\text { Average } \\
\text { p-values }\end{array}$ \\
\hline \multirow{4}{*}{$\begin{array}{c}\text { 1989-2008 } \\
\text { (Total period) }\end{array}$} & Average return & $46.30 \%$ & $5.29 \%$ & $19.32 \%$ & 41.01 p.p. & 0.0001 \\
\hline & Compound return & $22.26 \%$ & $-3.12 \%$ & $9.50 \%$ & 25.38 p.p. & - \\
\hline & Cumulative return & $5469.24 \%$ & $-46.92 \%$ & $513.66 \%$ & 5516.16 p.p. & - \\
\hline & Average Beta & 0.65 & 0.68 & 0.67 & -0.03 & - \\
\hline \multirow{4}{*}{$\begin{array}{l}\text { 1989-1998 } \\
\text { (First half) }\end{array}$} & Average return & $57.50 \%$ & $3.05 \%$ & $17.29 \%$ & 54.46 p.p. & 0.0142 \\
\hline & Compound return & $12.97 \%$ & $-8.29 \%$ & $1.54 \%$ & 21.26 p.p. & - \\
\hline & Cumulative return & $238.67 \%$ & $-57.90 \%$ & $16.48 \%$ & 296.57 p.p. & - \\
\hline & Average Beta & 0.70 & 0.69 & 0.70 & 0.02 & - \\
\hline \multirow{4}{*}{$\begin{array}{l}\text { 1999-2008 } \\
\text { (Second half) }\end{array}$} & Average return & $35.09 \%$ & $7.53 \%$ & $21.36 \%$ & 27.56 p.p. & 0.0000 \\
\hline & Compound return & $32.31 \%$ & $2.35 \%$ & $18.08 \%$ & 29.97 p.p. & - \\
\hline & Cumulative return & $1544.46 \%$ & $26.09 \%$ & $426.85 \%$ & 1518.37 p.p. & - \\
\hline & Average Beta & 0.59 & 0.68 & 0.64 & -0.08 & - \\
\hline \multirow{4}{*}{$\begin{array}{c}\text { 1989-1993 } \\
\text { (pre-Plano Real) }\end{array}$} & Average return & $107.15 \%$ & $15.44 \%$ & $36.34 \%$ & 91.71 p.p. & 0.0409 \\
\hline & Compound return & $20.98 \%$ & $-4.64 \%$ & $6.80 \%$ & 25.62 p.p. & - \\
\hline & Cumulative return & $159.20 \%$ & $-21.13 \%$ & $38.95 \%$ & 180.33 p.p. & - \\
\hline & Average Beta & 0.79 & 0.79 & 0.80 & -0.01 & - \\
\hline \multirow{4}{*}{$\begin{array}{c}\text { 1994-2008 } \\
\text { (post-Plano Real) }\end{array}$} & Average return & $26.01 \%$ & $1.91 \%$ & $13.65 \%$ & 24.11 p.p. & 0.0000 \\
\hline & Compound return & $22.69 \%$ & $-2.61 \%$ & $10.41 \%$ & 25.30 p.p. & - \\
\hline & Cumulative return & $2048.62 \%$ & $-32.71 \%$ & $341.63 \%$ & 2081.32 p.p. & - \\
\hline & Average Beta & 0.60 & 0.64 & 0.63 & -0.04 & - \\
\hline \multirow{4}{*}{$\begin{array}{c}\text { Bear Markets } \\
(89,90,92,95 \\
98,00,01,02 \\
08)\end{array}$} & Average return & $-10.21 \%$ & $-27.89 \%$ & $-15.60 \%$ & 17.68 p.p. & 0.0001 \\
\hline & Compound return & $-15.03 \%$ & $-30.81 \%$ & $-19.11 \%$ & 15.78 p.p. & - \\
\hline & Cumulative return & $-76.91 \%$ & $-96.37 \%$ & $-85.18 \%$ & 19.46 p.p. & - \\
\hline & Average Beta & 0.64 & 0.72 & 0.70 & -0.08 & - \\
\hline \multirow{4}{*}{$\begin{array}{c}\text { Bull Markets } \\
\text { (remaining years) }\end{array}$} & Average return & $107.12 \%$ & $27.24 \%$ & $47.49 \%$ & 79.88 p.p. & 0.0013 \\
\hline & Compound return & $64.66 \%$ & $27.61 \%$ & $40.28 \%$ & 37.05 p.p. & - \\
\hline & Cumulative return & $24021.02 \%$ & $1360.94 \%$ & $4040.76 \%$ & 22660.08 p.p. & - \\
\hline & Average Beta & 0.62 & 0.66 & 0.65 & -0.04 & - \\
\hline \multirow{4}{*}{$\begin{array}{c}\text { Contractions } \\
(90,91,92,98 \\
99,01,03)\end{array}$} & Average return & $99.72 \%$ & $17.82 \%$ & $42.09 \%$ & 81.90 p.p. & 0.0067 \\
\hline & Compound return & $45.62 \%$ & $8.42 \%$ & $27.48 \%$ & 37.19 p.p. & - \\
\hline & Cumulative return & $1288.20 \%$ & $76.15 \%$ & $447.05 \%$ & 1212.05 p.p. & - \\
\hline & Average Beta & 0.59 & 0.66 & 0.65 & -0.08 & - \\
\hline \multirow{4}{*}{$\begin{array}{c}\text { Expansions } \\
\text { (remaining years) }\end{array}$} & Average return & $17.53 \%$ & $-1.46 \%$ & $7.07 \%$ & 18.99 p.p. & 0.0001 \\
\hline & Compound return & $11.28 \%$ & $-8.81 \%$ & $0.89 \%$ & 20.09 p.p. & - \\
\hline & Cumulative return & $301.18 \%$ & $-69.87 \%$ & $12.18 \%$ & 371.05 p.p. & - \\
\hline & Average Beta & 0.68 & 0.69 & 0.68 & -0.01 & - \\
\hline
\end{tabular}

Risk analysis tells the same story. Value outperformed growth by a sizeable premium in all states of the economy. Attention should be drawn to the fact that the value portfolio's outperformance during economic contractions was much greater than during 
expansions. Value's betas were somewhat smaller (save for the sample's first half). Thus, our results echo the ones found by Lakonishok et al. (1994) and suggest that value stocks are less risky and yield higher returns, in stark contrast to the EMS's propositions.

Panels A and B of Table 5 show the results for the one-dimensional P/B-sorted portfolios and the two-dimensional portfolios, respectively. Results were smaller than $\mathrm{P} / \mathrm{E}$ sorted portfolios' but, in both strategies, value stocks confirmed their dominance: compound value premium totaled $19.22 \%$ when applying the two-dimensional strategy and $18.34 \%$ when sorting on $\mathrm{P} / \mathrm{Bs}$. Thus, contrary to Lakonishok et al. (1994), we did not find better results for the two-dimensional strategies, as the corresponding figure for the P/E-sorted portfolios was $25.38 \%$.

We believe $\mathrm{P} / \mathrm{Bs}$ ' (and as a consequence, the two-dimensional's) underperformance may be due to the fact that investors buy stocks expecting future cash flows. Graham and Meredith (1998) argue that book value may be an important metric in security analysis only in exceptional cases and that the success of an investment depends primarily on its earning power. Therefore, it would be reasonable to expect that $\mathrm{P} / \mathrm{E}$ - a metric that captures earning power - would perform better than $\mathrm{P} / \mathrm{B}$, which is an indicator of the hard assets of the company, which may be outdated or obsolete.

Table 5 Results for one-dimensional P/B-sorted portfolios and for two-dimensional portfolios

\begin{tabular}{|c|c|c|c|c|c|c|}
\hline \multicolumn{7}{|c|}{ PANEL A: Results for one-dimensional P/B-sorted portfolios } \\
\hline Period & Metric & $\begin{array}{l}\text { Quartile } 1 \\
\text { (value) }\end{array}$ & $\begin{array}{c}\text { Quartile } 4 \\
\text { (growth) }\end{array}$ & Total sample & $\begin{array}{l}\text { Average value } \\
\text { premium } \\
\text { (Q1-Q4) }\end{array}$ & $\begin{array}{l}\text { Average } \\
\text { p-values }\end{array}$ \\
\hline \multirow{4}{*}{$\begin{array}{c}\text { 1989-2008 } \\
\text { (Total period) }\end{array}$} & Average return & $30.42 \%$ & $3.21 \%$ & $19.32 \%$ & 27.21 p.p. & 0.0001 \\
\hline & Compound return & $15.68 \%$ & $-2.66 \%$ & $9.50 \%$ & 18.34 p.p. & - \\
\hline & Cumulative return & $1740.81 \%$ & $-41.69 \%$ & $513.66 \%$ & 1782.50 p.p. & - \\
\hline & Average Beta & 0.72 & 0.66 & 0.67 & 0.06 & - \\
\hline \multirow{4}{*}{$\begin{array}{l}\text { 1989-1998 } \\
\text { (First half) }\end{array}$} & Average return & $30.94 \%$ & $-7.64 \%$ & $17.29 \%$ & 38.58 p.p. & 0.0034 \\
\hline & Compound return & $4.92 \%$ & $-12.97 \%$ & $1.54 \%$ & 17.89 p.p. & - \\
\hline & Cumulative return & $61.60 \%$ & $-75.07 \%$ & $16.48 \%$ & 136.67 p.p. & - \\
\hline & Average Beta & 0.72 & 0.68 & 0.70 & 0.04 & - \\
\hline \multirow{4}{*}{$\begin{array}{l}\text { 1999-2008 } \\
\text { (Second half) }\end{array}$} & Average return & $29.90 \%$ & $14.06 \%$ & $21.36 \%$ & 15.84 p.p. & 0.0045 \\
\hline & Compound return & $27.54 \%$ & $8.87 \%$ & $18.08 \%$ & 18.67 p.p. & - \\
\hline & Cumulative return & $1039.10 \%$ & $133.90 \%$ & $426.85 \%$ & 905.20 p.p. & - \\
\hline & Average Beta & 0.72 & 0.63 & 0.64 & 0.08 & - \\
\hline \multirow{4}{*}{$\begin{array}{c}\text { 1989-1993 } \\
\text { (pre-Plano Real) }\end{array}$} & Average return & $57.58 \%$ & $-3.44 \%$ & $36.34 \%$ & 61.02 p.p. & 0.0195 \\
\hline & Compound return & $7.23 \%$ & $-13.11 \%$ & $6.80 \%$ & 20.34 p.p. & - \\
\hline & Cumulative return & $41.74 \%$ & $-50.48 \%$ & $38.95 \%$ & 92.23 p.p. & - \\
\hline & Average Beta & 0.80 & 0.80 & 0.80 & 0.00 & - \\
\hline \multirow{4}{*}{$\begin{array}{c}\text { 1994-2008 } \\
\text { (post-Plano Real) }\end{array}$} & Average return & $21.37 \%$ & $5.43 \%$ & $13.65 \%$ & 15.94 p.p. & 0.0005 \\
\hline & Compound return & $18.64 \%$ & $1.10 \%$ & $10.41 \%$ & 17.55 p.p. & - \\
\hline & Cumulative return & $1198.69 \%$ & $17.75 \%$ & $341.63 \%$ & 1180.94 p.p. & - \\
\hline & Average Beta & 0.69 & 0.61 & 0.63 & 0.08 & - \\
\hline
\end{tabular}


continued

\begin{tabular}{|c|c|c|c|c|c|c|}
\hline Period & Metric & $\begin{array}{c}\text { Quartile } 1 \\
\text { (value) }\end{array}$ & $\begin{array}{l}\text { Quartile } 4 \\
\text { (growth) }\end{array}$ & Total sample & $\begin{array}{l}\text { Average value } \\
\text { premium } \\
(\mathrm{Q} 1-\mathrm{Q})\end{array}$ & $\begin{array}{l}\text { Average } \\
\text { p-values }\end{array}$ \\
\hline \multirow{4}{*}{$\begin{array}{c}\text { Bear Markets } \\
(89,90,92,95 \\
98,00,01,02 \\
08)\end{array}$} & Average return & $-12.39 \%$ & $-20.35 \%$ & $-15.60 \%$ & 7.96 р.p. & 0.1631 \\
\hline & Compound return & $-18.44 \%$ & $-23.58 \%$ & $-19.11 \%$ & 5.15 p.p. & - \\
\hline & Cumulative return & $-84.02 \%$ & $-91.11 \%$ & $-85.18 \%$ & 7.09 p.p. & - \\
\hline & Average Beta & 0.73 & 0.73 & 0.70 & 0.00 & - \\
\hline \multirow{4}{*}{$\begin{array}{c}\text { Bull Markets } \\
\text { (remaining years) }\end{array}$} & Average return & $72.13 \%$ & $15.42 \%$ & $47.49 \%$ & 56.72 p.p. & 0.0001 \\
\hline & Compound return & $53.96 \%$ & $18.65 \%$ & $40.28 \%$ & 35.31 p.p. & - \\
\hline & Cumulative return & $11422.73 \%$ & $556.14 \%$ & $4040.76 \%$ & 10866.59 p.p. & - \\
\hline & Average Beta & 0.68 & 0.63 & 0.65 & 0.05 & - \\
\hline \multirow{4}{*}{$\begin{array}{c}\text { Contractions } \\
(90,91,92,98 \\
99,01,03)\end{array}$} & Average return & $52.00 \%$ & $18.80 \%$ & $42.09 \%$ & 33.21 p.p. & 0.0790 \\
\hline & Compound return & $27.22 \%$ & $13.77 \%$ & $27.48 \%$ & 13.45 p.p. & - \\
\hline & Cumulative return & $439.22 \%$ & $146.65 \%$ & $447.05 \%$ & 292.57 p.p. & - \\
\hline & Average Beta & 0.68 & 0.67 & 0.65 & 0.01 & - \\
\hline \multirow{4}{*}{$\begin{array}{l}\text { Expansions } \\
\text { (remaining years) }\end{array}$} & Average return & $18.80 \%$ & $-5.18 \%$ & $7.07 \%$ & 23.98 p.p. & 0.0002 \\
\hline & Compound return & $9.91 \%$ & $-10.50 \%$ & $0.89 \%$ & 20.41 p.p. & - \\
\hline & Cumulative return & $241.38 \%$ & $-76.36 \%$ & $12.18 \%$ & 317.74 p.p. & - \\
\hline & Average Beta & 0.74 & 0.65 & 0.68 & 0.09 & - \\
\hline
\end{tabular}

PANEL B: Results for two-dimensional portfolios

\begin{tabular}{|c|c|c|c|c|c|c|}
\hline Period & Metric & $\begin{array}{l}\text { Portfolio } 1 \\
\text { (value) }\end{array}$ & $\begin{array}{l}\text { Portfolio } 9 \\
\text { (growth) }\end{array}$ & Total sample & $\begin{array}{l}\text { Average value } \\
\text { premium } \\
\text { (P1-P4) }\end{array}$ & $\begin{array}{l}\text { Average } \\
\text { p-values }\end{array}$ \\
\hline \multirow{4}{*}{$\begin{array}{c}\text { 1989-2008 } \\
\text { (Total period) }\end{array}$} & Average return & $36.57 \%$ & $6.45 \%$ & $19.32 \%$ & 30.13 p.p. & 0.0000 \\
\hline & Compound return & $18.70 \%$ & $-0.52 \%$ & $9.50 \%$ & 19.22 p.p. & - \\
\hline & Cumulative return & $2983.10 \%$ & $-9.94 \%$ & $513.66 \%$ & 2993.04 p.p. & - \\
\hline & Average Beta & 0.69 & 0.67 & 0.67 & 0.02 & - \\
\hline \multirow{4}{*}{$\begin{array}{l}\text { 1989-1998 } \\
\text { (First half) }\end{array}$} & Average return & $41.94 \%$ & $-0.15 \%$ & $17.29 \%$ & 42.09 p.p. & 0.0020 \\
\hline & Compound return & $9.42 \%$ & $-8.55 \%$ & $1.54 \%$ & 17.97 p.p. & - \\
\hline & Cumulative return & $145.92 \%$ & $-59.09 \%$ & $16.48 \%$ & 205.01 p.p. & - \\
\hline & Average Beta & 0.71 & 0.68 & 0.70 & 0.03 & - \\
\hline \multirow{4}{*}{$\begin{array}{l}\text { 1999-2008 } \\
\text { (Second half) }\end{array}$} & Average return & $31.21 \%$ & $13.05 \%$ & $21.36 \%$ & 18.16 p.p. & 0.0001 \\
\hline & Compound return & $28.77 \%$ & $8.21 \%$ & $18.08 \%$ & 20.56 p.p. & - \\
\hline & Cumulative return & $1153.70 \%$ & $120.15 \%$ & $426.85 \%$ & 1033.55 p.p. & - \\
\hline & Average Beta & 0.66 & 0.66 & 0.64 & 0.00 & - \\
\hline \multirow{4}{*}{$\begin{array}{c}\text { 1989-1993 } \\
\text { (pre-Plano Real) }\end{array}$} & Average return & $77.30 \%$ & $6.91 \%$ & $36.34 \%$ & 70.39 p.p. & 0.0081 \\
\hline & Compound return & $14.70 \%$ & $-7.91 \%$ & $6.80 \%$ & 22.61 p.p. & - \\
\hline & Cumulative return & $98.55 \%$ & $-33.75 \%$ & $38.95 \%$ & 132.30 p.p. & - \\
\hline & Average Beta & 0.80 & 0.79 & 0.80 & 0.00 & - \\
\hline \multirow{4}{*}{$\begin{array}{c}\text { 1994-2008 } \\
\text { (post-Plano Real) }\end{array}$} & Average return & $23.00 \%$ & $6.29 \%$ & $13.65 \%$ & 16.70 p.p. & 0.0000 \\
\hline & Compound return & $20.06 \%$ & $2.07 \%$ & $10.41 \%$ & 17.99 p.p. & - \\
\hline & Cumulative return & $1452.82 \%$ & $35.95 \%$ & $341.63 \%$ & 1416.87 p.p. & - \\
\hline & Average Beta & 0.65 & 0.63 & 0.63 & 0.02 & - \\
\hline
\end{tabular}


continued

\begin{tabular}{|c|c|c|c|c|c|c|}
\hline Period & Metric & $\begin{array}{l}\text { Portfolio } 1 \\
\text { (value) }\end{array}$ & $\begin{array}{c}\text { Portfolio } 9 \\
\text { (growth) }\end{array}$ & Total sample & $\begin{array}{l}\text { Average value } \\
\text { premium } \\
\text { (P1-P4) }\end{array}$ & $\begin{array}{l}\text { Average } \\
\text { p-values }\end{array}$ \\
\hline \multirow{4}{*}{$\begin{array}{c}\text { Bear Markets } \\
(89,90,92,95, \\
98,00,01,02, \\
08)\end{array}$} & Average return & $-11.53 \%$ & $-22.01 \%$ & $-15.60 \%$ & 10.48 p.p. & 0.0012 \\
\hline & Compound return & $-16.60 \%$ & $-25.15 \%$ & $-19.11 \%$ & 8.54 p.p. & - \\
\hline & Cumulative return & $-80.48 \%$ & $-92.62 \%$ & $-85.18 \%$ & 12.14 p.p. & - \\
\hline & Average Beta & 0.69 & 0.73 & 0.70 & -0.04 & - \\
\hline \multirow{4}{*}{$\begin{array}{c}\text { Bull Markets } \\
\text { (remaining years) }\end{array}$} & Average return & $85.79 \%$ & $24.26 \%$ & $47.49 \%$ & 61.53 p.p. & 0.0002 \\
\hline & Compound return & $58.44 \%$ & $25.54 \%$ & $40.28 \%$ & 32.90 p.p. & - \\
\hline & Cumulative return & $15696.12 \%$ & $1120.63 \%$ & $4040.76 \%$ & 14575.49 p.p. & - \\
\hline & Average Beta & 0.65 & 0.64 & 0.65 & 0.01 & - \\
\hline \multirow{4}{*}{$\begin{array}{c}\text { Contractions } \\
(90,91,92,98 \\
99,01,03)\end{array}$} & Average return & $70.96 \%$ & $22.14 \%$ & $42.09 \%$ & 48.82 p.p. & 0.0138 \\
\hline & Compound return & $35.46 \%$ & $15.56 \%$ & $27.48 \%$ & 19.90 p.p. & - \\
\hline & Cumulative return & $736.83 \%$ & $175.16 \%$ & $447.05 \%$ & 561.67 p.p. & - \\
\hline & Average Beta & 0.64 & 0.65 & 0.65 & -0.02 & - \\
\hline \multirow{4}{*}{$\begin{array}{c}\text { Expansions } \\
\text { (remaining years) }\end{array}$} & Average return & $18.06 \%$ & $-2.00 \%$ & $7.07 \%$ & 20.06 p.p. & 0.0016 \\
\hline & Compound return & $10.55 \%$ & $-8.23 \%$ & $0.89 \%$ & 18.78 р.p. & - \\
\hline & Cumulative return & $268.43 \%$ & $-67.27 \%$ & $12.18 \%$ & 335.69 p.p. & - \\
\hline & Average Beta & 0.71 & 0.68 & 0.68 & 0.03 & - \\
\hline
\end{tabular}

Table 6 presents a summary of the compound annual returns, permitting easy comparison of all strategies tested.

Table 6 Summary of findings

\begin{tabular}{|c|c|c|c|c|c|}
\hline Period & Ratios & Value Portfolio & $\begin{array}{l}\text { Growth } \\
\text { Portfolio }\end{array}$ & Value Premium & $\begin{array}{c}\mathrm{H}_{\mathrm{o}} \text { rejected at the } \\
10 \% \text { level? }\end{array}$ \\
\hline \multirow{3}{*}{$\begin{array}{l}\text { 1989-2008 } \\
\text { (Total period) }\end{array}$} & $\mathrm{P} / \mathrm{E}$ & $22.26 \%$ & $-3.12 \%$ & 25.38 р.p. & Yes \\
\hline & $\mathrm{P} / \mathrm{B}$ & $15.68 \%$ & $-2.66 \%$ & 18.34 p.p. & Yes \\
\hline & $P / E+P / B$ & $18.70 \%$ & $-0.52 \%$ & 19.22 p.p. & Yes \\
\hline \multirow{3}{*}{$\begin{array}{l}\text { 1989-1998 } \\
\text { (First half) }\end{array}$} & $\mathrm{P} / \mathrm{E}$ & $12.97 \%$ & $-8.29 \%$ & 21.26 p.p. & Yes \\
\hline & $\mathrm{P} / \mathrm{B}$ & $4.92 \%$ & $-12.97 \%$ & 17.89 p.p. & Yes \\
\hline & $\mathrm{P} / \mathrm{E}+\mathrm{P} / \mathrm{B}$ & $9.42 \%$ & $-8.55 \%$ & 17.97 p.p. & Yes \\
\hline \multirow{3}{*}{$\begin{array}{l}\text { 1999-2008 } \\
\text { (Second half) }\end{array}$} & $\mathrm{P} / \mathrm{E}$ & $32.31 \%$ & $2.35 \%$ & 29.96 p.p. & Yes \\
\hline & $\mathrm{P} / \mathrm{B}$ & $27.54 \%$ & $8.87 \%$ & 18.67 p.p. & Yes \\
\hline & $P / E+P / B$ & $28.77 \%$ & $8.21 \%$ & 20.56 p.p. & Yes \\
\hline \multirow{3}{*}{$\begin{array}{l}\text { 1989-1993 } \\
\text { (pre-Plano Real) }\end{array}$} & $\mathrm{P} / \mathrm{E}$ & $20.98 \%$ & $-4.64 \%$ & 25.62 p.p. & Yes \\
\hline & $\mathrm{P} / \mathrm{B}$ & $7.23 \%$ & $-13.11 \%$ & 20.34 p.p. & Yes \\
\hline & $P / E+P / B$ & $14.70 \%$ & $-7.91 \%$ & 22.61 p.p. & Yes \\
\hline \multirow{3}{*}{$\begin{array}{l}\text { 1994-2008 } \\
\text { (post-Plano Real) }\end{array}$} & $\mathrm{P} / \mathrm{E}$ & $22.69 \%$ & $-2.61 \%$ & 25.30 p.p. & Yes \\
\hline & $\mathrm{P} / \mathrm{B}$ & $18.64 \%$ & $1.10 \%$ & 17.54 p.p. & Yes \\
\hline & $P / E+P / B$ & $20.06 \%$ & $2.07 \%$ & 17.99 p.p. & Yes \\
\hline \multirow{3}{*}{$\begin{array}{l}\text { Bear markets } \\
(89,90,92,95,98, \\
00,01,02,08)\end{array}$} & $\mathrm{P} / \mathrm{E}$ & $-15.03 \%$ & $-30.81 \%$ & 15.78 p.p. & Yes \\
\hline & $\mathrm{P} / \mathrm{B}$ & $-18.44 \%$ & $-23.58 \%$ & 5.14 p.p. & No \\
\hline & $P / E+P / B$ & $-16.60 \%$ & $-25.15 \%$ & 8.55 p.p. & Yes \\
\hline
\end{tabular}




\begin{tabular}{l|c|c|c|c|c}
\hline \multicolumn{1}{c|}{ Period } & Ratios & Value Portfolio & $\begin{array}{c}\text { Growth } \\
\text { Portfolio }\end{array}$ & Value Premium & $\begin{array}{c}\text { Ho rejected at the } \\
\mathbf{1 0} \% \text { level? }\end{array}$ \\
\hline \multirow{2}{*}{$\begin{array}{l}\text { Bull markets } \\
\text { (remaining years) }\end{array}$} & $\mathrm{P} / \mathrm{E}$ & $64.66 \%$ & $27.61 \%$ & 37.05 p.p. & Yes \\
\cline { 2 - 6 } & $\mathrm{P} / \mathrm{B}$ & $53.96 \%$ & $18.65 \%$ & 35.31 p.p. & Yes \\
\cline { 2 - 6 } & $\mathrm{P} / \mathrm{E}+\mathrm{P} / \mathrm{B}$ & $58.44 \%$ & $25.54 \%$ & 32.90 p.p. & Yes \\
\hline \multirow{2}{*}{$\begin{array}{l}\text { Contractions } \\
\text { (90, 91, 92, 98, 99, } 3 \text { ) }\end{array}$} & $\mathrm{P} / \mathrm{E}$ & $45.62 \%$ & $8.42 \%$ & 37.20 p.p. & Yes \\
\cline { 2 - 6 } & $\mathrm{P} / \mathrm{B} / \mathrm{E}+\mathrm{P} / \mathrm{B}$ & $35.46 \%$ & $15.56 \%$ & 19.90 p.p. & Yes \\
\hline \multirow{2}{*}{$\begin{array}{l}\text { Expansions } \\
\text { (remaining years) }\end{array}$} & $\mathrm{P} / \mathrm{E}$ & $11.28 \%$ & $-8.81 \%$ & 20.09 p.p. & Yes \\
\cline { 2 - 7 } & $\mathrm{P} / \mathrm{B}$ & $9.91 \%$ & $-10.50 \%$ & 20.41 p.p. & Yes \\
\cline { 2 - 7 } & $\mathrm{P} / \mathrm{E}+\mathrm{P} / \mathrm{B}$ & $10.55 \%$ & $-8.23 \%$ & 18.78 p.p. & Yes \\
\hline
\end{tabular}

The value strategy's superiority can be easily grasped by focusing on the fifth column, which shows the pervasive and sizeable value premium. Table 5 also highlights the remarkable results produced by the $\mathrm{P} / \mathrm{E}$-sorted portfolios. Compared to the other strategies, spreads only lagged during expansions by a tiny margin (0.32\%); they otherwise ranged from a minimum of $1.74 \%$ to a maximum of $23.75 \%$. The null hypothesis was not rejected only during bear markets when sorting on $\mathrm{P} / \mathrm{Bs}$. Also noteworthy is the fact that both portfolios showed a positive performance during economic contractions, suggesting stock markets' tendency to anticipate economic improvements.

Graph 1 below portrays the evolution of a $\$ 1$ invested in each strategy throughout the holding period. Also shown is the real return (i.e., inflation-adjusted) of the Ibovespa Index, the most comprehensive stock index for the Brazilian stock market.

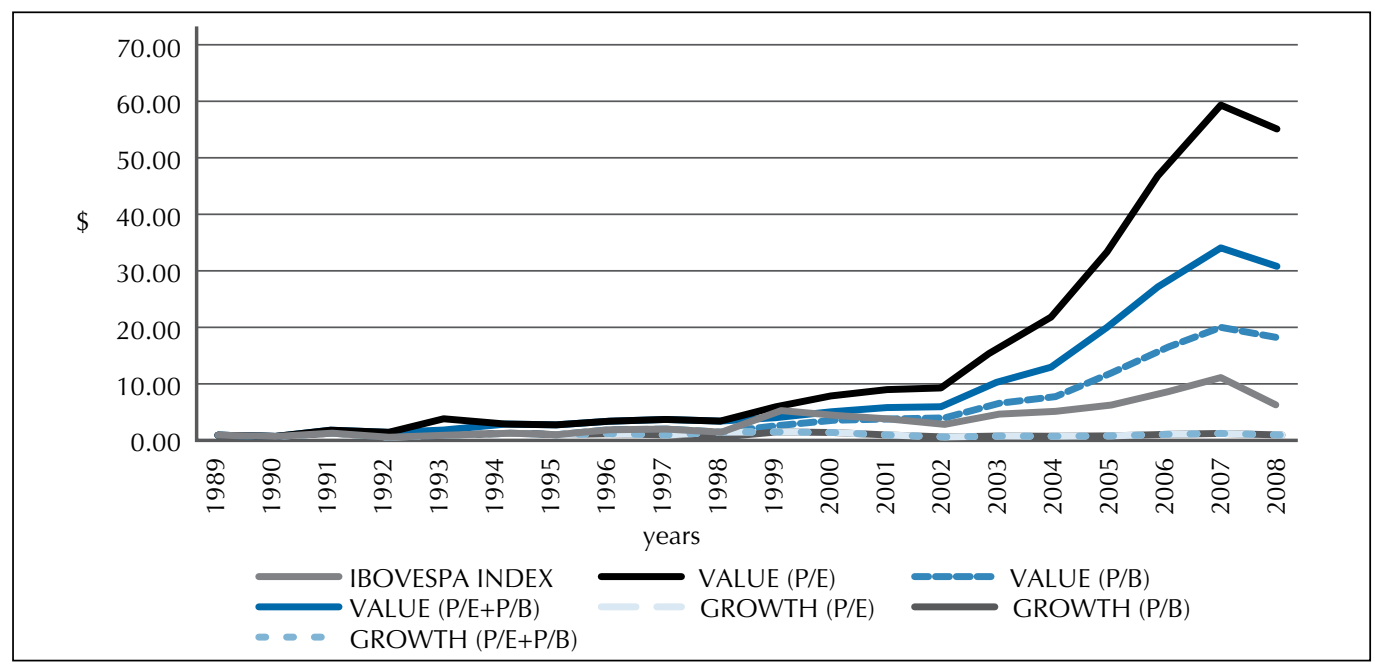

Graph 1 Evolution of a \$1 invested in each strategy on a linear scale

Given the methodological and time frame differences, it is not possible to draw direct comparisons between our results and those of other Brazilian studies. Nonetheless, it is worth of notice that, according our computations, Braga and Leal (2004) found a 18.55 p.p. yearly value spread on $\mathrm{P} / \mathrm{B}$-sorted portfolios. This is similar to our 17.89 p.p. spread found in a similar period (1989-1998). On the other hand, Lucena et al (2008) found a yearly spread of $53.01 \%$ p.p. (our computations), which is significantly higher than our yearly $23.30 \%$ p.p. for a similar period. 
Given the spread in returns and their wide publicity, one may legitimately wonder why they persist. After all, if investors are confident that value always yields higher returns, they will bid value stock prices higher, cancelling out their oversized returns.

It seems safe to say that human behavior represents the key factor. Ferguson (2008, p. 174) argues that "so long as human expectations of the future veer from over optimism to over pessimism, from fear to greed, stock prices will tend to trace a line not unlike the jagged peaks of the Andes". Financialhistory islittered with overreactions and excesses of unreasonable expectations: tulips traded at prices as high as house prices in Amsterdam (CHANCELLOR, 2000), investors greedy enough to believe in $40 \%$ returns over a 45-day stretch on the famous Ponzi scheme (KINDLEBERGER, 2005), market value of a subsidiary higher than its holding company's (SHILLER, 2005) or, to tread a recent terrain, the ironically called NINJA mortgages (No Income, No Job and no Assets) securitized as investment grade bonds, during the subprime bubble (Ferguson, 2008). In general, the excesses of pessimism reverberate much more fiercely than the preceding euphoria, providing excellent buying opportunities for those who do not share the apocalyptic vision then prevalent on the market. Thus, given the paramount importance of erratic human behavior, flagrantly ignored in the paradigms and models of the EMS, it is reasonable to expect that speculative bubbles, massive liquidity injections and the increase of correlations and reflexivity on global financial markets will keep on sparking exaggerated oscillations in stock prices.

\section{CONCLUSIONS}

Our results confirm the copious previous research on Value Investing's risks and returns. Value premium, as measured by the spread in returns between the value and the growth portfolios, averaged a compound $25.38 \%$ a year on $\mathrm{P} / \mathrm{E}$-sorted portfolios, $18.34 \%$ on $\mathrm{P} / \mathrm{B}$-sorted portfolios and $19.22 \%$ on twodimensional portfolios. Thus, $\mathrm{P} / \mathrm{E}$ proved to be the best selection criterion.

Risk analysis suggests that value stocks are not riskier than growth stocks. Our value portfolios outperformed growth portfolios in each and every state of the economy analyzed and even managed to produce higher returns on economic contractions than on economic expansions. Also noteworthy is the fact that beta has shown not to be an adequate risk measure. Value's betas were either smaller or marginally higher than growth's, even though the former returns were remarkably higher. These results echo Fama and French's (1992). Value's superior performance may be associated to behavioral and agency issues.

\section{References}

ATHANASSAKOS, George. Value versus growth stock returns and the value premium: the Canadian experience 1985-2005. Canadian Journal of Administrative Sciences, Hamilton, v. 26, n. 2, p. 109-121, June 2009. BARBERIS, Nicholas; THALER, Richard. A Survey of Behavioral Finance. In: CONSTANTINIDES, G.M.; HARRIS M.; STULZ, R. M. (eds.), Handbook of the Economics of Finance. 1. ed, v. 1. Amsterdam: Elsevier, 2003.
BASU, S. Investment performance of common stocks in relation to their price-earnings ratios: a test of the efficient market hypothesis. The Journal of Finance, Oxford, v. XXXII, n. 3, p. 663-682, July 1977. BRAGA, Cláudio A. B. M.; LEAL, Ricardo P. C. Ações de Valor e de Crescimento nos anos 1990. In: BONOMO, Marco (Org.). Finanças Aplicadas ao Brasil. 2. Ed. Rio de Janeiro: Editora FGV, 2004. 
BRAZILIAN CENTRAL BANK. Gross Domestic Product and Growth Rates. [S.1.: s.n.], 2010. Available at: <http:// www.bcb.gov.br/?INDECO >. Acessed in: Feb., 10 $0^{\text {th }}, 2010$. BUFFET, Warren E. Berkshire Hathaway 2009 Annual Report. [S.1: s.n.], 2010. Available at: $<$ http://www. berkshirehathaway.com/2009ar/2009ar.pdf >. Accessed on Feb., $10^{\text {th }}, 2010$.

CHAN, Louis K. C.; LAKONISHOK, Josef. Value and growth investing: review and update. Financial Analysts Journal, Charlottsville, v. 60, n. 1, p. 71-96, Jan./Feb. 2004. CHANCELLOR, Edward. Devil take the hindmost: $a$ history of financial speculation. Nova York: Penguin, 2000. CHIN, Jim Y.F.; PREVOST, Andrew K.; GOTTESMAN, Aron A. Contrarian investing in a small capitalization market: evidence from New Zealand. Financial Review, Oxford, v. 37, n. 3, p. 421-446, Aug. 2002.

DEBONDT, Werner F.; THALER, Richard H. Anomalies: a mean-reverting walk down Wall Street. Journal of Economic Perspectives, Nashville, v. 3, n. 1, p. 189202, winter 1989.

Does the stock market overreact? The Journal of Finance, Oxford, v. XL, n. 3, p. 793-805, July 1985. DIMSON, Elroy; MUSSAVIAN, Elroy. A brief history of market efficiency. European Financial Management, Oxford, v. 4, n. 1, p. 91-103, 1998.

FAMA, Eugene F.; FRENCH, Kenneth R. The crosssection of expected stock returns. The Journal of Finance, Oxford, v. XLVII, n. 2, p. 427-465, June 1992.

FERGUSON, Niall. The ascent of money: a financial history of the world. New York: Penguin, 2008.

GALDI, Fernando Caio. Estratégias de investimento em ações baseadas na análise de demonstrações contábeis: é possível prever o sucesso? 2008. 119p. Tese (Doutorado) Faculdade de Economia, Administração e Contabilidade, Universidade de São Paulo, São Paulo, 2008.

GRAHAM, Benjamin. The intelligent investor. Revised edition. New York: Collins, 2006.

; DODD, David. Security analysis. New York:

McGraw-Hill, 1934.

; MEREDITH, Spencer. The interpretation of financial statements: the classic 1937 edition. New York: HarperCollins, 1998.

GREENWALD, C. N. et al. Value investing: from Graham to Buffett and beyond. Hoboken: John Wiley \& Sons, 2001.

KINDLEBERGER, Charles P. Manias, panics, and crashes: a history of financial crises. Hoboken: Wiley, 2005. LAKONISHOK, Josef; SHLEIFER, Andrei; VISHNY, Robert W. Contrarian investment, extrapolation and risk. The Journal of Finance, Oxford, vol. XLIX, n. 5, p. 1541-1578, Dec. 1994.

LOPES, Alexsandro Broedel; GALDI, Fernando Caio. Does financial statement anaylis generate abnormal returns under extremely adverse conditions? In: VII Encontro Brasileiro de Finanças, 2007, São Paulo. Anais eletrônicos. São Paulo: FGV, 2007. Available at: <http:// www.fucape.br/_admin/upload/prod_cientifica/Lopes_ Does_Financial.pdf $>$. Accessed on: Feb, $13^{\text {th }} 2011$. MANDELBROT, Benoit. The misbehavior of markets: a fractal view of risk, ruin \& reward. New York: Basic Books, 2004.

RAMOS, Patrícia Barros; PICANÇO, Marcelo B.; COSTA Jr., Newton C. A. da. Retornos e riscos das value e growth stocks no mercado brasileiro. In: COSTA Jr, Newton C. A. da; LEAL, Ricardo P. C.; LEMBRUGER, Eduardo F. (Org.). Mercado de Capitais: análise empírica no Brasil. São Paulo: Atlas, 2000.

ROSTAGNO, Luciano Martin; SOARES; Karina Talamini Costa; SOARES, Rodrigo Oliveira. Estratégias de valor e de crescimento em ações na BM\&FBovespa: uma análise de nove indicadores relacionados ao risco. In: III Encontro Brasileiro de Finanças, 2003, São Paulo. Anais eletrônicos. São Paulo: FGV, 2003. Available at: <http://virtualbib. fgv.br/dspace/handle/123456789/1223>. Acessed on: December $19^{\text {th }} 2008$.

SHILLER, Robert J. Irrational exuberance. 2. ed. New York: Currency Doubleday, 2005.

ZWEIG, Jason. Your money and your brain: how the new science of neuronomics can help make you rich. New York: Simon and Schuster, 2007. 